\title{
Ottoman Damascus during the Tanzimat: The New Visibility of Religious Distinctions
}

\author{
A. Massot
}

In the nineteenth century Damascus was characterized by inter-confessional tensions that culminated in an attack, in 1860, against the Christian neighborhood of the city; many Christians lost their lives or property. Relations between religious groups in Damascus during the Tanzimat period were shaped both by local events and, during this period of foreign intervention and military defeats, by a variety of issues related to imperial sovereignty. This context led to a dichotomous image of the Ottoman city and its population: on the one side Christians were perceived to be allied with foreign powers-France, Russia, and to a lesser extent England - and on the other, Muslims were seen as loyal to the Ottoman authorities. Christians were also at the center of the power struggle between two authorities, the foreign consuls and the Ottoman governors, and this contributed to a politicization of religious distinctions. This struggle not only underlined conflicts over space and visibility but was also shaped by them. In this paper I first explore the political and social context of the Tanzimat and the ways in which public space was transformed into a tool for social change. Second, I examine the relation between the consuls and the governors, and address the issue of the struggle for sovereignty and its spatial dynamics. Finally, I look at the case of conversions as one arena in which these dynamics materialized.

\section{Laying the Foundations of a New Order: The Tanzimat and Visibility}

\section{The Context of the Tanzimat in Bilād al-Shām}

In the first part of the nineteenth century, the Ottoman Empire witnessed a vast array of internal and external changes of an economic, societal, and political nature. In terms of its foreign policy, the Sublime Porte suffered military and diplomatic defeats by Russia in 1812, 1829, and during the Crimean war (1853-1856). Simultaneously, it faced revolts and internal secession threats from Greece (1821-1830), Serbia (1804-1817), and Walachia (1829), ultimately 
leading to the independence or autonomy of those regions. The sultan's rule over the Bilādal-Shäm was challenged by his own viceroy of Egypt, Muhammad 'Alī, who conquered the region in 1831 and retained it until 1841. The various revolts and secessions were in some degree supported by foreign powers. The empire, conscious of its military weakness, embarked on a vast program of reforms, which were limited, initially, to the military but soon spread to the societal and political fields. One of the consequences of these changes was a reshuffling of existing social and political hierarchies.

In order to finance these costly reforms, the empire took loans from European countries and was forced to allow for a greater intervention of foreign representatives in its own affairs. New capitulations were signed and foreign ambassadors and consuls were given greater influence in political matters. The enactment of the reforms relied on internal cash flows through new forms of taxation and mandatory military conscription. These changes met with rebellion by various groups in Syria, especially by the Maronites and Druzes in Mount Lebanon ${ }^{1}$ and in the Hawran. ${ }^{2}$ One of the main concerns of the reformers was the promotion of loyalty to the empire in this context of internal threats and secessions. Inter-confessional relations in Damascus must be understood in this context of imperial transformations, foreign intervention, and internal rebellion.

\section{Clothing as a Tool of Reform}

Public space, which is understood here to include clothing, visibility, as well as the built environment, played an important role in the struggles for legitimacy and power in this changing context. From the start of the Tanzimat period, visibility and clothing were strongly politicized and thereby shaped into signs of loyalty. This dynamic was emphasized by Mahmud II (1808-1839) who emphasized the idea that the sultan, rather than the state, was to be the focus of loyalty of the subjects. This new allegiance was to be displayed through clothing. Mahmud II saw the adoption of European clothing fashions as a betrayal that damaged the success of Ottoman production and challenged social hierarchies. He thus promoted a 'buy Ottoman' clothing campaign. ${ }^{3}$

1 Joel Beinin, Workers and Peasants in the Modern Middle East (Cambridge/New York: Cambridge University Press, 2001), 31; The consular correspondance in the Foreign Office (F.O.) $78 / 447$ describes the issues of taxation in Mount Lebanon at length.

2 F.o. $78 / 872$, Wood-Palmerstone, 28 June 1857.

3 Donald Quataert, "Clothing Laws, State, and Society in the Ottoman Empire, 1720-1829," International Journal of Middle Eastern Studies 29, no. 3 (1997), 411. 
His rule was also famous for the abolition of the institution of the Janissaries in 1826; this act marked the beginning of the reform period. The lack of military preparedness of the Janissaries and their involvement in civil affairs was seen as the cause of the military weakness of the empire and its defeats at the hand of Russia. ${ }^{4}$ A new army was created to replace this institution. At the same time, a new military hierarchy was adopted and presented to the populace in new uniforms. Homogeneity was promoted through the imposition of the fez, which replaced former sartorial customs that were based on status and represented by various turbans. ${ }^{5}$ Turbans displayed one's religion, rank, wealth, and occupation, while the fez came to represent the equidistance of all subjects to the state. This change in clothing was part of the centralization process, which aimed at eliminating intermediaries and shifting relationships of loyalty and patronage exclusively towards the state. Other measures included the creation of regional councils designed to give rise to a new group of individuals who did not belong to the traditional elite. ${ }^{6}$

While in earlier periods displays of allegiance were predominantly directed towards local power structures, in this period these displays were shifted toward the state. The previously flexible internal hierarchy of Ottoman cities was slowly replaced by a top-down order based on the principle of loyalty to the state rather than on status. Clothing policies show this new direction and the attempt to shape the bodies of the Ottoman subjects to promote political change. This focus on clothing persisted throughout the Tanzimat period.

\section{Laying the Foundations: The Egyptian Occupation (1831-1841)}

The Tanzimat were inaugurated in the capital in 1839 while Muhammad Alī was still ruling Biläd al-Shām from Egypt. The Egyptian occupation of the region introduced significant changes in the political, societal, and economic fabric of the formerly Ottoman cities. Some of these changes persisted even after their retreat from Syria. ${ }^{7}$ Most importantly for inter-confessional rela-

4 Carter V. Findley, Bureaucratic Reform in the Ottoman Empire: The Sublime Porte, 1789-1922 (Princeton, NJ: Princeton University Press, 1980), 114-115.

5 Quataert, "Clothing Laws," 412.

6 George Ramez Tomeh, "Landownership and Political Power in Damascus 1858-1958" (American University of Beirut, 2007), 20.

7 Khālid Banī Hānī, Tārīkh Dimashq wa- ulāmāiha khilāl al-ḥukm al-Mișrī, 1831-184o (Damascus: Dār Șafahạt, 2007), 191; Bruce Alan Masters, Christians and Jews in the Ottoman Arab World: The Roots of Sectarianism (Cambridge, New York: Cambridge University Press, 2001), 135 . 
tions, the Egyptian governor relied heavily on Christians in the administration, while the power of the Jews was reduced. ${ }^{8}$ Their power was curtailed even further after the arrest or execution of some of the important members of their community during the infamous blood libel of $1840 .{ }^{9}$ In the beginning of the nineteenth century, the Jewish Fārhị family had had the upper hand in its political battle with the Melkite Bahrī family, and the former had obtained important posts in the financial administration. ${ }^{10}$ Under Muhammad 'Alī, represented in Damascus by Sharîf Pasha, the Bahrī family was favored, and Hanna Bahrī was awarded the post of financial administrator. ${ }^{11}$ The house of the mufti of Damascus was made into his residence. ${ }^{12}$ The other members of the majlis were very critical of Hanna Bahrī, who was publicly awarded medals; jokes were made to the effect that he was the actual leader of the country. ${ }^{13}$ The fact that he was in charge of the collection of taxes furthered the resentment of the population against Melkites. ${ }^{14}$

The reliance of Muhammad 'Alī on Melkites can be understood as a result of the fact that he was supported politically by France, which assumed the role of protector of Uniate Christians. Jews could only count on the support of Austria and to a lesser extent England, which eventually allied with the Ottoman Empire against Muhammad 'Alī. ${ }^{15}$ Favoring Melkites was a way for Muhammad 'Alì to gain further support from his main ally and to secure its eventual military intervention against the empire. ${ }^{16}$ This Egyptian policy was represented spatially by the building of additional churches and the enlargement of existing ones. ${ }^{17}$ This period was also marked by the inauguration of foreign consulates in Damascus, a change that radically altered the political landscape of the city.

8 Yitzhak Hofman, "The Administration under Egyptian Rule," in Moshe Ma'oz (ed.), Studies on Palestine during the Ottoman Period (Jerusalem: Magnes Press, 1975), 321.

$9 \quad$ For a description of the blood libel, see Jonathan Frankel, The Damascus Affair (Cambridge: Cambridge University Press, 1997).

10 Ibrāhīm 'Awra, Tārīkh wilāya Sulāyman Basha al-'ādil yashtamilu 'ala tārīkh Filasțīn waLubnān, ed. al-Kuri Qustanțin al-Basha (Sayda: Matba'āt Dār al-Mukkhāllis, 1936), 90. Mudhakkirat tārīkhiyya 'an hamlat Ibrāhīm Basha 'ala Sūriya, ed. Aḥmad Ghassān Sabanu (Damascus: Dār Qutayba, 1980), 59.

12 Banī Hānī, Tārīkh Dimashq, 157.

13 Mudhakkirat tārīkhiyya, 59.

14 F.0. 78/1520, Brant-Bulwer, 30 August 1860; Hofman, "Administration," 321.

15 Frankel, Damascus Affair, 19.

16 Ibid., 61.

17 Stefan Weber, Damascus: Ottoman Modernity and Urban Transformation (1808-1918) (Aarhus: Aarhus University Press, 2009), 2:51-62. 
While many Damascenes had initially supported the Egyptian occupation, it quickly became unpopular because of increased taxation, military conscription, and symbolic spatial actions in favor of the Christians and foreign powers and against the 'ulama $\vec{a}^{3}{ }^{18}$ The use of mosques and schools, the pride of Damascene society, as barracks for the soldiers or as biscuit factories are often described and remembered as a source of outrage against the Egyptian occupation. ${ }^{19}$ Resentments fueled by Muhammad 'Alī's rule were translated into bitterness towards Christians and especially Melkites. ${ }^{20}$

The position of Christians in Damascus thus changed during the Egyptian occupation as a result of the interference of foreign powers, the problem of Ottoman sovereignty, and the political role of Christian communities. All of these developments had important consequences on the way Christians acted and were perceived in the Tanzimat period, as well as on official policies towards them.

\section{The Ottoman Tanzimat Period: Ambiguities of the Reforms}

The Ottomans recovered Bilād al-Shām from Muhammad 'Alī in 1841 principally as a result of the intervention of England. France did not intervene militarily on behalf of its ally. The Ottoman state continued the restructuring initiated by Muhammad 'Alī and introduced further reforms. The two main decrees that were drafted in the Tanzimat period were the Gülhane edict of 1839, which was applied to the recovered lands, and the Islahat Fermanı of 1856 . The Gülhane edict promised the instauration of justice regarding the collection of taxes, conscription, and the execution of punishments. It guaranteed Ottoman subjects' property, honor, and life, using the classic vocabulary of the circle of justice. ${ }^{21}$ A central aspect of the Tanzimat reforms, which had important consequences

\footnotetext{
18 Banī Hānī, Tārīkh Dimashq, 79, 80.

19 Weber, Damascus, 1:116.

20 Itzchak Weismann, "Law and Sufism on the Eve of Reform: The Views of Ibn 'Abidin" in Itzchak Weismann and Fruma Zachs (eds.), Ottoman Reform and Muslim Regeneration (New York: I.B. Tauris, 2005), 72.

21 See the decree in Jacob C. Hurewitz (ed.), The Middle East and North Africa in World Politics (New Haven, ст: Yale University Press, 1975-1979), 1:269; The circle of justice is an Islamic political concept which shows causal relationships between a just government, the prosperity of its subjects, the financial resources of the state, and military power. It is basically the idea that good governance ensures the survival and strength of the state. On the history of this notion see L.T. Darling, A History of Social Justice and Political Power in the Middle East: The Circle of Justice From Mesopotamia to Globalization (New York: Routledge, 2013).
} 
for inter-confessional relations, was the emphasis on appearances and public space, designed to be tools of social and political change.

After the return of the Ottomans to Damascus in 1841, a firman was drafted for the protection of non-Muslims; this allowed them to wear whatever clothing they pleased and to ride on horseback without being molested. In the same year, some Christians were attacked in the city of Damascus and their white turbans - a color previously reserved for Muslims - were torn off their heads. ${ }^{22}$ Policies fostering clothing equality were supposed to promote social and political equality. However, because such policies were lobbied for by foreign political powers, they tended to polarize religious groups. The fact that this firman was brought from Istanbul to the governor Necip Pasha by the British consul Mr. Wood indicates the extent of foreign involvement in clothing policies. ${ }^{23}$

The Islahat Fermanı of 1856 shows a radical change in the legitimization of power and in the political discourse on subjecthood. The decree of 1839 was addressed to all subjects of the empire. In contrast, the decree of 1856 was directed especially towards Christians. The sentence that is used repeatedly is: "All the Christians and other non-Muslims." ${ }^{24}$ This decree proclaims the equality of all subjects but it is clear that it was drafted primarily to reassure Christians of their rights and to maintain the 'privileges' allegedly awarded to their leadership by former sultans. ${ }^{25}$ 'Alī and Fü'âd Pasha composed this decree with the help of the French, British, and Austrian ambassadors. ${ }^{26}$ It was also a strategic tool to counter the hostile intentions of European representatives present at the Paris Peace Conference of $1856 .{ }^{27}$ The decree guaranteed that no one could be forced to convert or could be harassed because of religious beliefs. ${ }^{28}$ Freedom of religion was presented mainly as a question of visibility. The decree awarded non-Muslims the rights to build churches and synagogues, to hold crosses in processions, to ring church bells, and to participate in the council, the political instrument of the Tanzimat. Discourses over religious

\footnotetext{
22 F.o. 78/447, Wood-Earl of Aberdeen, 20 November 1841.

23 F.o. 78/447, Wood-Necib Pasha, 13 November 1841.

24 Weber, Damascus, 1:316.

25 Ibid., 1:316-318.

26 Butrus Abu-Manneh, "The Later Tanzimat and the Ottoman Legacy in the Near Eastern Successor States," in Camille Mansour and Leila Fawaz (eds.), Transformed Landscapes: Essays on Palestine and the Middle East in Honor of Walid Khalidi (Cairo: American University of Cairo Press, 2009), 69.

27 Ceasar E. Farah, The Politics of Interventionism in Ottoman Lebanon, 1830-1861 (London: I.B. Tauris, 2000), 729 .

28 Hurewitz, Middle East, 1:316-318.
} 
rights became associated with the increasing visibility and perceived economic and political success of the Christian population, represented spatially by the beautiful houses of the Christian elite and the luxurious decorations of the various churches of the neighborhood of Bab Tuma. ${ }^{29}$

This decree put an end to the specific status of non-Muslims in the empire but also enforced the loss of fiscal privileges of the 'ulama' and ashrāf, who were previously exempt from paying taxes. ${ }^{30}$ It reminded the population that because taxes were collected equally from all subjects, everyone could be drafted into the army. ${ }^{31}$ Previously, non-Muslims were required to pay a poll tax in lieu of army service. The conscription of non-Muslims was never put into practice. Indeed, the majority of Jews and Christians were not eager to send their sons to the army and the government was not enthusiastic to enroll them. ${ }^{32}$

Resentments towards the reform decrees, especially the Islahat Fermani, existed in many parts of the empire, including Damascus. ${ }^{33}$ The decrees were resented mainly because they meant increased taxation, conscription, and they introduced changes in the social hierarchies. The French consul reported that the famous amir 'Abd al-Qādir al-Jazāirin criticized these reforms in his presence, describing them as contrary to religion. ${ }^{34}$ All these laws were enacted in a period in which the intervention of foreign powers and their economic advantages caused resentment among the population. ${ }^{35}$ Indeed the decree was drafted after the Crimean war, in which France, Britain, and the Ottoman Empire opposed Russia. The immediate cause of the Crimean war was the competing claims by France and Russia for the protection of the holy places and of Ottoman Christians. The war corresponds to the arrival of French and British armies in the vicinity of Istanbul, to their increasing involvement in internal affairs, and to the increasing debt of the empire. ${ }^{36}$ It is described in the chronicles as marking an important turn in inter-confessional relations in the empire.

\footnotetext{
29 F.0. 78/1520, Brant-Bulwer, 30 August 1860.

30 Hurewitz, Middle East, 1:316-318.

$31 \quad$ Ibid., 1:316-318.

32 Ahwwāl al-nașāra ba'd al-ḥarb al-qaram, ms Catalogue Cheikho (Beirut: Saint Joseph University), 24, 25 .

33 Affaires Etrangères, Correspondance Politique des Consuls/Turquie/Damas, OutreyWalewski, 19 March 1857 and 25 March 1856; Leila Tarazi Fawaz, An Occasion for War: Civil Conflict in Lebanon and Damascus (Berkeley: University of California Press, 1994), 69.

34 Archives Etrangères (A.E.) Correspondance Politique des Consuls (CPC)/ Turquie/Damas, Bullar-Walewski, 21 January 1857.

35 Tarazi Fawaz, An Occasion for War, 68-69.

36 Butrus Abu-Manneh, Studies on Islam and the Ottoman Empire in the 19th Century (18261876) (Istanbul: Isis Press, 2001), 113.
} 
The author of Ahwwāl al-nașāra ba'd al-ḩarb al-qaram, a contemporary Christian chronicle, explains that Damascene Muslims were against the sultan's involvement in this war. They expected that negative consequences would arise from it, such as increased conscription and taxation. ${ }^{37}$ It would also impel the empire to make more concessions to European powers, especially those related to their protection of local Christians and their right of intervention in Ottoman affairs. The chronicler recalls that during the war the population was hostile to the Christians and insults became more common. ${ }^{38}$ The British consul Mr. Wood corroborated this observation and reported seeing a circular that called for the expulsion of foreign consuls and for the execution of the French consul and the Melkite patriarch. ${ }^{39}$ The drafting of a similar petition occurred in 1841 after the reconquest of Damascus by the sultan under the governorship of Necip Pasha. ${ }^{40}$ It is not always clear who took the initiative of writing such petitions; they were usually signed by famous notables, who were subject to a certain level of pressure from the governors. Thus, these petitions do not necessarily represent the sentiments of the population. However, when their timing coincided with periods of publicly expressed resentment towards Christians, as was the case in 1841 and 1856 , it can be assumed that they indicate a certain level of discontent towards Europeans.

The author of Ahwāl al-nașāra ba'd al-harb al-qaram stated that the decree of 1856 aimed to put an end to this aggressiveness by forbidding insults and by awarding Christians administrative posts. He noted, however, that this was not enough to curb resentments regarding the Crimean war, as these remained strong. ${ }^{41}$ Both the international context and the wording of the reforms led to bitterness towards Christians and foreign powers.

It should be noted that the Tanzimat reforms, dictated from Istanbul and enacted in the provinces, were not applied uniformly throughout the Ottoman lands. The Ottoman 'state' apparatus was composed of different levels and involved a variety of actors, including civilians; thus the border between 'state' and 'society' was somewhat blurred. Individuals at each of these different levels of the state, but especially at the city level, had an opportunity to shape the application of the Tanzimat. Each city, with its own set of political actors, therefore had a different experience of the Tanzimat period. Christian and Jewish communities in different regions of the empire also differed in number,

37 Ahwwāl al-nașāra, 5, 29.

38 Ibid., $5,29$.

39 F.o. 195/368, Wood-Stratford de Redcliffe, 13 July 1853.

$40 \quad$ F.O. 78/447, Wood-Reshid Pasha, 18 October 1841.

41 Aḥwāl al-nașāra, 5, 29. 
sect, and societal role. For this reason, it is crucial to consider local dynamics and interpersonal relations together with an exploration of the actual wording of the reforms in order to grasp the consequences of the reforms on interconfessional relations.

\section{Consuls and Governors: Competition and Sovereignty}

\section{The Issue of Protection}

Beyond the structural factors described above, the politicization of religious identities was shaped on a daily basis through inter-personal relations, especially between the consuls and the governor. At the root of many conflicts between these two individuals lay a difference of interpretation of the Tanzimat. ${ }^{42}$ The ambiguities in the formulation of the reforms, as well as in the right of intervention given to representatives of foreign powers, led to a deterioration of the relations between the consuls and the governor and contributed to the formation of a sectarian and polarized political landscape. Their numerous altercations had strong repercussions on the population because the consuls and the governors came to be seen as representatives of the different religious communities. Because of their dramatic aspect and visibility, political and diplomatic conflicts had the tendency to translate into animosities among the population.

The conflicts that arose often revolved around the issue of protection of local Christians and Jews. The British, French, Russian, and Austrian consuls were in constant competition to attract the loyalty of Damascene Christians; they attempted to do this by presenting themselves as the spokesperson of the Christians to the Ottoman government. They took advantage of minor conflicts to expand their influence by arguing that the honor of their country was at stake in each of those skirmishes, thus turning them into diplomatic issues. ${ }^{43}$ Behind this competition lay a struggle for influence and economic advantage in the vast territories of the empire. Their interventions in the name of non-Muslims gave them a gateway into local politics and provided them with negotiating power with Istanbul.

42 See, for example, the conflict that took place between the father at the convent of Nazareth and the consul of France regarding the attribution of French protection to Ottoman Christians in A.E. CPC/Turquie/Damas, Bourville-Villardel, 7 February 1848.

For example, a financial dispute between a Muslim and an Ottoman Christian named Mr. Maksoud became a diplomatic conflict after the intervention of the English consul Mr. Wood, in A.E. CPC/Turquie/Damas, Ratti-Menton-Guizot, 23 February 1842. 
The protection statuses were based on different types of rationales. First, the consuls attributed protection to Ottoman subjects whom they employed. This protection was thus dependent on an individual's temporary situation. However, in this period another idea of protection was developed, this was based on the religious community to which one belonged rather than on one's employment status. To be sure, the claim that foreign powers were the protectors of local Christian and Jewish communities was not a new phenomenon, but it became a legal reality in the nineteenth century. The rights, previously vague and ambiguous, of France and Russia to protect, respectively, Uniates and Orthodox Christians and to administer the holy places were conceded officially. ${ }^{44}$ However, the extent of that protection and its practical application remained a source of confusion. The various consuls, governors, and Christian Ottomans conceived the status of protégé in a very different manner, and their conception changed throughout the reform period. ${ }^{45}$

Initially the status of protégé was exclusively reserved for individuals working for the consulates. Those protégés, mostly dragomans and writers, were to be treated as foreigners and benefit from the same rights, including exemption from certain taxation and extra-territoriality. But the consuls abused this right and awarded it to individuals who did not work for them. In 1847, when the French consul was asked by the governor to list the protégés working for the consul, it became clear that this was an issue of potential conflict. The protégés knew how to use the consuls for their own benefit and behaved arrogantly. He also described the outcry that his creation of an official list of protégés had generated among the Damascene Christians. ${ }^{46}$

Some individuals benefiting from protégé status also took advantage of their position to engage in fraudulent financial activities. ${ }^{47}$ Richard Edwards, a British traveler who visited Syria in this period, strongly criticized the abuses of the protection system and related the various intrigues he observed among the protégés. ${ }^{48} \mathrm{He}$ also described the financial aspect of the protection sys-

44 Orlando Figes, The Crimean War: A History (New York: Metropolitan Books, 2010), 109.

45 In 1853, the French and British consuls had an altercation regarding the rights and obligations linked to the status of protégé, after a Brisith protégé was taken into the French consulate, F.0. 195/368, Wood-Barbet de Jouy, 31 March 1853.

46 A.E. 166/Po/D2o/3, Annex to de Bourville-Bourquency, 11 December 1847.

47 An example is that of Mr. Gedei, employed by the British consulate, who was charged with dishonest commercial activities, F.O. 195/368, Wood-Barbet de Jouy, 23 March 1853; Another example is the dragoman Mr. Misk who used his position to commit financial fraud, F.o. 195/601, Brant-Bulwer, 6 February 1860.

48 Richard Edwards, La Syrie 1840-1862, histoire, politique, administration, population, religion 
tem and claimed that consular agents, having spent a great deal to attain their post, would try to regain their resources through the sale of protection statuses. In turn, protégés would rent their protection to individuals presented as their coworkers, family members, etc. ${ }^{49}$ This accusation is corroborated by the British consul in $1860 .{ }^{50}$ These practices delegitimized all foreign agents in the eyes of the population, who saw them as opportunists fleeing their responsibilities. ${ }^{51}$ Dragomans also had a considerable amount of power, consuls relied solely on their testimony and translations to determine their actions in relation to the Ottoman governors. Dragomans could use this dependence to further their own interests, or to blackmail the Ottoman official and in this manner deliberately worsen the relationship of these two individuals. ${ }^{52}$ Ottoman subjects who had acceded to foreign nationality could also become vice-consuls. ${ }^{3}$

Richard Wood, the British consul in 1846, recognized that abuses of protection were the cause of many conflicts with the governor. ${ }^{54}$ The Ottoman governors resented the attribution of protection because it removed those individuals from their authority. In 1836 the British consul rationalized the protection by arguing that dragomans' subjection to Ottoman authorities would threaten their integrity and their service to the foreign consulates. He also recommended that the children of dragomans be awarded protection from birth rather than when they reached majority in order to ensure the loyalty of their parents. ${ }^{55}$ But the protection status was abused to avoid punishment. Indeed, if a judiciary case involved a protégé, the trial would take place in the consulate rather than before the Ottoman authorities, and this would obviously favor the protégé rather than the Ottoman subject. ${ }^{56}$ One of the abuses described by Richard Edwards was the practice of granting protection statuses temporarily to individuals who wanted to escape the law, or win a trial. ${ }^{57}$

et mœurs, évènements de 1860 d'après des actes officiels et des documents authentiques (Paris: Amyot, 1862), 80.

Ibid., 77; F.o. 78/291, Farren-Cambell, 18 February 1836 and 28 February 1836.

$50 \quad$ F.o. $78 / 1520$, Brant-Bulwer, 15 December 1860.

F.O. 195/226, Wood-Canning, 29 July 1844.

52 Edwards, Syria, 79.

53 F.o. 78/1520, Brant-Bulwer, 15 December 1860.

54 Foreign Office 195/226, Wood-Canning, 8 April 1846.

55 F.o. 78/291, Farren-Cambell, 28 February 1836.

$56 \quad$ Edwards, Syria, 78.

57 Ibid., 80. 
The distinction between legal and religious protection was not defined clearly. It was also not clear to what extent Ottoman subjects enjoyed rights given to foreigners and if Ottoman courts could prosecute foreigners. ${ }^{58}$ In 1847 the French consul, Mr. de Bourville, who had recently arrived in the city, argued that claims made by protégés who were trying to escape Ottoman jurisdiction was not justified by any law and that it was contrary to the Capitulations. ${ }^{59}$

The governors also saw the issue of protection as an impediment to the enactment of their fiscal reforms. The supposed exemption of foreign nationals from paying any kind of taxes, the excessive attribution of foreign protection to Ottoman subjects and especially rich merchants, frustrated governors and gave the protégés an unfair advantage. For example, in 1846 the governor 'Alī Pasha refused to recognize the British protection granted in $1841^{60}$ to two Jewish merchants, the Harārī brothers, because the protection status could not be awarded without the sultan's authorization. ${ }^{61} \mathrm{He}$ demanded that they pay a tax on property — the so called 'virgo' - instead of the individual ferde tax collected from Ottoman subjects. ${ }^{62}$ During the Tanzimat, taxation was a very sensitive issue, as it came to be required of all subjects of the empire and was an indicator of loyalty to the modern state. Even the French consul in 1847 contested the rationality behind the exemption of taxes for all the protégés and declared that it would be better to apply this exemption solely to dragomans. ${ }^{63}$ The issue of protection, but also conversion, was problematic as it challenged administrative categories and taxation practices and called into question the relation of the individual to the state.

The relation between Ottoman subjects who became protégés and the Ottoman state was complex. They were neither fully foreign nor fully Ottoman subjects and their relations to the different political actors and the local communities were changeable. This in-between position not only propelled them to the middle of the political scene but also caused tensions among different authorities who disagreed about how they should be treated. However, despite

58 Marie Carmen Smyrnelis, Identités et Relations Sociales à Smyrne aux XVIIIe et XIXe siècles (Leuven: Peeters Publishers, 2005), 85.

59 A.E. 166/Po/D2o/3, Annex to de Bourville-Bourquency, 11 December 1847.

6o F.o. $78 / 447$, Wood-Bidwell, 29 September 1841.

61 F.o. 195/226, Aly Pasha-Wood, 27 March 1846.

62 F.o. 195/226, Wood-Canning, 8 April 1846; F.o. 195/226; Translation of 'Alī Pasha's note to Mr. Wood, 21 March 1846.

63 A.E. 166/Po/D20/3, Annex to de Bourville-Bourquency, 11 December 1847. 
of the fact that Christians and Jews were instrumentalized in this power struggle, they had a certain level of agency and could make the most of the situation to further their interests.

\section{Spaces of Competition}

The issue of sovereignty and extra-territoriality has spatial dynamics. The protection provided by foreign powers challenged the individual's belonging to the community, the city, and the empire, as it offered them different forms to escape this relation, principally by attaching oneself to a new territory. By gaining a protected status, the individual partly extracted himself from the social fabric of the city and its internal hierarchies, while remaining engaged in certain aspects of the social and economic life. The attribution of protection was more than a legal status: it affected the nature of the public space by enacting administrative, political, economic, and social practices that questioned the sovereignty of the Ottoman state and the system of local hierarchies.

Public space became an important arena in which the struggle for sovereignty between consuls and governors materialized. Cases of Christian religious processions with foreign symbols and displays of foreign flags on churches have been described elsewhere as examples of the politicization of public space. ${ }^{64}$ The public display of Christian religious identity, such as using crosses in processions, ringing church bells, enlarging churches, and emphasizing their outward decoration, contributed to the perception that Christians benefited economically and politically as a consequence of foreign intervention. ${ }^{65}$ However, other more mundane spaces were also at the center of those conflicts. The marketplace, for example, was an important place of competition between religious groups. Their protégé status allowed some Christians and Jews to benefit from the Capitulations by enjoying lower customs tax rates (at the same level as foreign merchants, who were increasingly visible in Ottoman markets during this period). ${ }^{66}$ Christians and Jews took advantage of those privileges to build fortunes through the commerce of grain, the sale of Euro-

64 Sibel Zandi-Sayek, "Orchestrating Difference, Performing Identity: Public Rituals in Nineteenth-Century Izmir," in Nezar AlSayyad (ed.), Hybrid Urbanism: On the Identity Discourse and the Built Environment, (Westport, Ст: Praeger, 2001).

65 Anais Massot, "Modernization, Communal Space and Inter-confessional Conflicts in 19th century Damascus," Syrian Studies Association Bulletin 17, no. 2 (2012): 12-15.

66 Beinin, Workers and Peasants, 45-47; Linda Schatkowski Schilcher, Families in Politics: Damascene Factions and Estates of the 18th and 19th Centuries (Wiesbaden: F. Steiner, 1985), 82. 
pean textiles, tax farming ${ }^{67}$ or by making loans with high interest rates $(20-24$ percent) to peasants and farmers. ${ }^{68}$ Christians employed by the government had opportunities to enrich themselves. ${ }^{69}$ In some commercial activities they rapidly gained the upper hand over the Muslim merchant class. At that time, many Christians were involved in the production of local textiles and benefited from advantages in this domain, in part because of their access to English yarn, which became necessary in order to produce textiles at affordable prices. This advantage created resentments among Muslim weavers who suffered more than their Christian counterparts from the introduction of European textiles in the nineteenth century. ${ }^{70}$

The economic competition led to increasing tension between Muslims and Christians; this culminated in violence during the massacre of 1860 . The riot started in the marketplace of Bab al-Barid, which specialized in the sale of European clothing, mostly by Muslims. ${ }^{71}$ The Christians who produced local textiles concentrated their workshops in the Christian neighborhood of Bab Tuma. It is significant that this neighborhood was described by the British consul in 1860 as a 'city in itself.' 72 During the violence of 1860 , the looms of Christians were destroyed. ${ }^{73}$ The various events of interpersonal violence involving Christians during the period from 1840 to 1860 often involved merchants or individuals working for them. ${ }^{74}$ The marketplace was thus a place where resentments towards Christians and their foreign allies were fueled.

Political aspects intertwined with religious distinctions in this violence, as it targeted specific Christian communities affiliated with foreign powers. Bab Tuma, the neighborhood where Catholic institutions were located, was heavily affected..$^{75}$ Catholic missions, churches, and the Greek Orthodox Patriarchate were primary targets of the 1860 riots, while the other churches were only

67 Beinin, Workers and Peasants, 45-47; Schatkowski Schilcher, Families in Politics, 82. For tax farming activities, see F.o. 195/368, Wood-Clarendon, 22 April 1853.

68 F.o. 195/368, Wood-Canning, 28 January 1851.

69 F.o. $78 / 1520$, Brant-Bulwer, 30 August 1860.

$70 \quad$ Schatkowski Schilcher, Families in Politics, 71, 74.

71 Tarazi Fawaz, An Occasion for War, 85.

72 F.0. $78 / 1520$, Brant-Bulwer, 13 June 1860.

73 Abdul-Karim Rafeq, "The Impact of Europe on a Traditional Economy: The Case of Damascus, 1840-1870," in Jean Louis Bacqué-Grammont and Pierre Dumont (eds.), Économie et Sociétés dans l'Empire Ottoman, fin du XVIIIe-début duxxe siècle: Actes du Colloque de Strasbourg, 1er-5 Juillet 1980 (Paris: Éditions du Centre national de la recherche scientifique, 1983), 422; Beinin, Workers and Peasants, 49.

74 For example, see F.0. 78/447, Wood-Necib Pasha, 13 November 1841.

75 Tarazi Fawaz, An Occasion for War, 100. 
affected by the general fire in the neighborhood. ${ }^{76}$ Mikhāîl Mishāqah, an eyewitness of the events, related that the main aim of the 1860 revolts were the Franciscan and Lazarist monasteries situated in the Catholic part of Mahalla al-Nașāra. ${ }^{77} \mathrm{He}$ argued that this violence was a consequence of the arrogant behavior of the Christians of Damascus. ${ }^{78}$ Another contemporary chronicler described the resentments of the population in this period as directed against the 'Franj' or Europeans. ${ }^{79}$ This specific targeting of Catholic and Greek Orthodox institutions demonstrates the political aspect of the violence of 1860 . The violence directed towards Catholic and Greek Orthodox places sought to target the influence of France and Russia. The British consulate, the main ally of the Ottoman Empire, was left untouched. ${ }^{80}$

Even though in certain areas of the city the politicization of religious identities created a tense atmosphere between religious groups, strong links of solidarity between Muslims and Christian continued to exist in certain neighborhoods, especially in the extra-mural Maydan. This area represented the local faction that often rebelled against the governor and the imposition of taxes and conscription. In this neighborhood, trade alliances in the booming commerce of grain were concluded across religious groups. ${ }^{81}$ The grain trade made up a significant portion of Syrian exports. Many new opportunities for a vast number of Damascenes and peasants were created in this field. ${ }^{82}$

During the events of 1860, Christians of this neighborhood were not attacked by the crowd and were protected by the local leaders. ${ }^{83}$ On various occasions, the inhabitants of Maydan displayed a strong neighborhood solidarity that cut across religious lines. For example, in 1857, during the controversy regarding the adoption of the Gregorian calendar, the Melkite inhabitants of Maydanwho supported the patriarch — were arrested after a fight with the opponents of the patriarch, many of whom were protégés or worked for the government.

76 Chantal Donzel-Verdeil, "Les Jésuites de Syrie (1830-1864): Une Mission auprès des Chrétiens d'Orient au début des Réformes Ottomanes" (PhD diss., University Paris IV Sorbonne, 2003), 166; Mikhāāl Mishāqah, Kitāb mashhad al-'ayan bi-hawādith Sūriya waLubnān, ed. Milham Khālis 'Abduh and Andrawus Hanna Shakhashiri (Cairo, 1908), 248; Weber, Damascus, 2:53-61.

77 Mishāqah, Kitāb mashhad al-'ayan, 248.

78 Ibid., 242.

79 Ahwō̄l al-nașāra, 22.

8o Tarazi Fawaz, An Occasion for War, 85, 89 .

81 Schatkowski Schilcher, Families in Politics, 62.

82 Ibid.

83 F.O. 195/6o1, Brant-Russell, 16 July 186o; Tarazi Fawaz, An Occasion for War, 85-89. 
A delegation composed of Christians and Muslims from Maydan then came to demand the release of their neighbors and ultimately attacked the residences of the opponents of the patriarch. ${ }^{84}$ Thus, the public sphere was not characterized by conflict in every area of Damascus. Although religious divisions were of political importance in the nineteenth century, one must keep in mind that in reality all groups were internally divided and that neighborhoods, as well as other societal units, remained strong bases of political solidarity.

\section{The Issue of Sovereignty at the Heart of the Conflict}

As the adoption of the fez demonstrated, clothing was a tool of political and social transformation. However, ways of dressing also became an important point of contestation in political struggles between different authorities. The case of Melkites wearing religious hats illustrates this struggle over sovereignty. In 1842 , following a previous attempt in the $1820 s,{ }^{85}$ the Greek orthodox clergy managed to obtain a firman from the sultan forbidding Melkite priests from wearing skullcaps or black headdresses similar to theirs, as these symbolized their belonging to the clergy. The Melkite priests were thus forced to dress as common people. ${ }^{86}$

The French consul described the dilemma that he faced in this conflict. He considered this firman unfair and wished to prevent its application, but he was also conscious that the Capitulations only allowed him to protect Latin Catholics. The extension of this protection to Uniates was tolerated in this early period of the Tanzimat but only on an occasional basis. In order not to be forced to take off their hats, the Melkite priests refused to go out of their houses. ${ }^{87}$ With the encouragement of the French consul some of them eventually went outside wearing the aforementioned hats. ${ }^{88}$ The governor, Necip Pasha, arrested them immediately. He then summoned one of the priests and asked him if he was a subject of the Sublime Porte or of France. When the latter responded that he was a subject of the sultan, Necip Pacha replied that while Uniates used to be the loyal subjects of the Porte, this was no longer the case because they disobeyed his directives and preferred to address themselves to the consul to resolve their problems. ${ }^{89}$

\footnotetext{
84 A.E. CPC/Turquie/Damas, Outrey-Walewski, 19 March 1857.

85 Mikhāāl Mishāqah, Murder, Mayhem, Pillage, and Plunder, trans. Wheeler M. Thackston (New York: State University of New York Press, 1988), 116.

86 A.E. CPC/Turquie/Damas, Ratti-Menton-Guizot, 4January 1842.

87 Ibid.

88 Ibid.

89 A.E. CPC/Turquie/Damas, Sieur Sayour-Beaudin, 3 January 1842.
} 
This example shows that clothing had become a locus of intra-Christian competition and was intertwined in questions of loyalty towards the Ottoman state. Conflicts between different Christian communities did not occur in a vacuum, but were inscribed in the general politics of the city, involving not only the Ottoman state but also different political factions from among the larger Muslim population.

Another case that illustrates problems of sovereignty caused by foreign intervention was the practice of sending petitions. The fact that some Ottoman subjects chose to address the consuls instead of the governors to file complaints or ask for favors was at the root of the tensions between those two parallel authorities. The petitions addressed to the consuls can be seen as challenges to Ottoman authority over its subjects and as part of a strategy by foreign powers to extend their jurisdiction in the empire by means of administrative practices. ${ }^{90}$ In the nineteenth century, many social, residential, administrative, and visual practices were perceived as political statements and as ways of taking sides in the conflict of sovereignty between the Ottoman Empire and foreign powers.

In cases of interpersonal or intercommunal disputes, there were a variety of possible authorities that Ottoman subjects could appeal to. While this enlarged their political possibilities, the presence of various authorities could also impede the ability of the plaintiff to obtain rapid retribution, especially when those cases became symbolic struggles for sovereignty.

The relations between consuls and governors were not only influenced by relations between the Porte and foreign powers, but also depended on power strategies. Governors' actions were linked to factional struggles in the empire. The period of the Tanzimat was characterized by ideological and political conflicts in Istanbul. Those conflicts revolved around debates on internal and external policy-making. Those divergences of opinion coincided with political factions that emerged around two main institutions, the bureaucracy (the Porte) and the entourage of the Sultan (the Palace), which was linked to the military institution. Those two factions disagreed regarding the nature of the Ottoman state and the role of the sultan, especially after the Gülhane edict of 1839. ${ }^{91}$ The balance of power tipped alternatively in favor of one or the other group during the period from 1830 to 1860 , generating shifts in imperial policies.

The governors that were sent to Damascus often belonged to the faction of the Palace, as was the case with the aforementioned Necip Pasha. The French

$90 \quad$ A.E. CPC/Turquie/Damas, Ratti-Menton-Guizot, 7 May 1841.

91 Abu-Manneh, Studies on Islam, 43, 44. 
consul in 1858 accused the military leaders of being involved in inciting hostility to the privileges of Europeans in the empire. ${ }^{92}$ They opposed certain reforms, especially those aimed at improving the situation of Christians and foreign consuls. Governors were ordered to solve issues arising between Christian sects in a rapid manner in order to avoid their evolution into diplomatic problems. ${ }^{93}$ However, in many cases, they did not follow those directives and, for a variety of reasons, exacerbated conflicts. They also tended to avoid the application of imperial decrees and ministerial letters. ${ }^{94}$ This political faction particularly resented the firman of 1856 because they saw it as a foreign imposition that was contrary to the interests of the Ottoman state, and because it represented the power of the bureaucrats. ${ }^{95}$ They especially refrained from applying the reforms concerning public space, which could work as faits accomplits in the favor of foreign consuls and Christian communities.

Consular agents were also involved in power struggles. They were either appointed from abroad or selected from within the consulate's employees. In either case a fierce competition took place. ${ }^{96}$ Once in power they pushed for the appointment of governors who would favor their interests and attempted to bring about their dismissal when they frustrated their goals. The accusation of mistreatment of Christians was an easy way to delegitimize governors. The competition for influence between consuls of European countries, especially between France and Britain, played an important role as well in their relation with the governors. ${ }^{97}$

Thus both governors and consular agents acted on the basis of various rationales, including consideration of international politics, factional struggles, and career enhancement. Those dynamics had the consequence of increasing

92 A.E. CPC/Turquie/Damas, Outrey-Walewski, 3 March $185^{8}$.

93 Selim Deringil, Conversion and Apostasy in the Late Ottoman Empire (Cambridge: Cambridge University Press, 2012), 5 .

94 For example, Osman Pasha, the governor of Damascus in 1848, refused to apply the order he received from Istanbul to punish the Damascenes who had attacked the funeral procession of the former consul of France, Mr. Combes, while it was entering the city center, as it was considered as an offense to the population, A.E. CPC/Turquie/Damas, Garnier-de Lhuys, 12 December 1848.

95 Butrus Abu-Manneh, "The Sultan and the Bureaucracy: The Anti-Tanzimat Concepts of Grand Vizier Mahmud Nedim Pasa," International Journal of Middle East Studies 22, no. 3 (1990), 266.

96 Edwards, Syria, $76-77$.

97 See, for example, the attempt by the British consul to get rid of Necip Pasha because of his good relation with the French consul and to replace him with 'Alī Pasha, who favored British and Austrian interests, A.E. CPC/Turquie/Damas, Ratti-Menton-Guizot, 7 May 1841. 
societal tensions, and reinforcing divisions between communities, especially those concerning issues of visibility and public space.

\section{Conversion as a Case Study}

\section{Conversion to Islam and Apostasy}

The issue of conversions aptly demonstrates the difficult relations between governors and consuls as well as the problems of sovereignty triggered by the intervention of foreign consuls. Conversion, which was problematic, involved the symbolic and often physical crossing of religious and social borders. The decree of 1839 made it legal, and the punishment of apostasy by death was abolished in 1844. The abolishment of the death penalty for apostasy was promoted by foreign powers in 1843 , after diplomatic problems arose in Istanbul when an Armenian who had converted to Islam, then returned to his previous religion and was sentenced to death for apostasy from Islam. This sentence created a profound diplomatic crisis. ${ }^{98}$ Foreign powers intervened to prevent the application of this sentence, and that intervention created problems of sovereignty. ${ }^{99}$ The decree of 1856 restated the legality of conversion. ${ }^{100}$ It was clear, however, that the Ottoman Empire did not wish to allow for conversion from Islam.

In most cases of conversion, the problems of apostasy were posed by converts to Islam who wished to return to their former religion. ${ }^{101}$ Thus, the Ottoman Empire conceived a legal process in order to avoid the death penalty in those cases by proving the invalidity of the first conversion. This was done by arguing that the first conversion had not been completely voluntary. This process meant that diplomatic issues could be avoided and discussions regarding the legality of conversion from Islam could be circumvented. ${ }^{102}$

Such cases of conversions from Christianity or Judaism to Islam put the empire in an uneasy position, and contributed to what Selim Deringil calls the

\footnotetext{
98 See the description of the events in Deringil, Conversion and Apostasy, 67-11; Abu-Manneh, Studies on Islam, 12.

99 Deringil, Conversion and Apostasy, 38.

100 Selim Deringil, "There is no Compulsion in Religion: On Conversion and Apostasy in the Late Ottoman Empire: 1839-1856," Comparative Study of Society and History 42, no. 3 (200o), $55^{6 .}$

101 Those are the vast majority of the cases described by the French and British Foreign Office archives. Some of those cases will be described below.

102 Deringil, Conversion and Apostasy, 44.
} 
"Imperial Headache."103 This type of conversion infuriated the original community to which the convert had belonged and called for the intervention of foreign consuls. A strictly regulated official legal process was put in place in order to ensure the voluntary nature of the conversion and to avoid further complications. ${ }^{104}$ State officials were advised not to let the population know about those cases, in an effort to calm potential tensions. ${ }^{105}$ These cases were to be referred to Istanbul directly, while in previous years the provincial government had dealt with them locally. This practice indicates that such cases were very sensitive for the empire and bureaucrats were clearly hoping to minimize the potentially conflictive consequences of these conversions. ${ }^{106}$ Governors, however, sometimes made matters worse by publicizing them. The clergy was also aware of the sensitive nature of conversions. When Mr. Khalīl, a Muslim, wanted to become Christian, the Greek Orthodox, Melkite, and Syrian Orthodox bishops refused to accept him into their church for fear of complications. He thus became Protestant. ${ }^{107}$

The French and British consuls of Damascus described at length various cases of conversion that were imbricated in political conflicts. For example, in $185^{\circ}$ a Greek Orthodox woman wanted to convert to Islam together with her son to follow the example of her husband. They went to see the judge, but when the boy was asked if this was what he wanted, he responded in the negative. After the case was made public, the woman was taken under the protection of the pasha but she was then kidnapped by a group of Greek Orthodox who took her to the Russian consulate. A diplomatic struggle erupted between the Russian consul and the pasha regarding the future of the child. ${ }^{108}$ Because consulates were places beyond the jurisdiction of the Ottoman representatives, they often served as refuges or prisons in cases involving local Christian or Jewish individuals who ran into conflict with the Ottoman authorities.

In the various provinces of the empire, the conversion cases often involved women and children. Indeed, many women converted in order to divorce or

\footnotetext{
103 Ibid., 28-66.

104 Ibid., 44.

105 Ibid., 38, 62.

106 Ibid., 66; The British consul Mr. Timoni describes the case of three children, two Christians and one Jew, who converted to Islam but then reverted and were sent away to prevent any problems after they took refuge in the British consulate, F.O. 195/226, Timoni-Canning, 26 August 1846; Deringil, Conversion and Apostasy, 38, 49.

107 F.O. 195/601, Brant-Alison, 20 April 1858.

108 A.E. CPC/Turquie/Damas, Vallegue-de la Hitte, 21 May 1850.
} 
to obtain guardianship over their children. ${ }^{109}$ For instance, in 1846 a Melkite woman converted to Islam in order to divorce her husband and marry a Muslim man but then changed her mind. Sälih Bey, the kaymakam, sent a letter to the British consul — who had been called to intervene by the Melkite vicar-stating that he would not prosecute her and knew of the discussions that took place in Istanbul two years before. However, when the case was brought to the council, Sālih Bey publicly announced that this apostasy was punishable by death. A few days later, however, the woman miraculously escaped and Sālị Bey forbade anyone to look for her. He also punished the man who had convinced her to convert. The British consul understood that Sālih Bey had to publicly threaten the woman in order to satisfy the members of the council, especially two who were particularly ill-disposed towards Christians and foreign powers, but that in reality he wanted to get rid of the case as discreetly as possible. ${ }^{110}$

This example shows that the strength and authority of the governors had a determinant influence on the resolution of the cases of conversion, especially when it involved foreign representatives. The governors were concerned both about reinforcing their local legitimacy to prevent rebellion and about satisfying foreign representatives who could appeal to Istanbul to replace them. Unfortunately, strengthening their legitimacy in the eyes of the local population often required showing strong resistance to foreign powers' interference. They thus had to find a balance between those two objectives. Each governor struck this balance in a different manner. This dynamic explains the seemingly hypocritical speech often used by governors and the reasons they politicized some cases while treating others in a more discreet manner.

Children could also use conversion to escape their parents' authority; such was the case of a seventeen years old Melkite girl who, because of the ill treatment she received from her mother, decided to become Muslim in order to be emancipated. ${ }^{111}$

Conversion had strong spatial dynamics because it was a shift of loyalty to a different authority. For example, in 1847, a Catholic Latin called Antoine/Selim Madim, who had converted to Islam many years before and married a Muslim woman, passed away. He was taken to be buried in the Muslim cemetery when the dragoman of the French consul stopped the procession and affirmed that he had returned to his original faith and had to be buried in the Christian

\footnotetext{
109 Deringil, Conversion and Apostasy, 38, 58.

110 F.o. 195/226, Timoni-Canning, 2 December 1846.

111 A.E. Serie D/166Po/ D2o/3, Beaudin-Baron de Bourquency, 14 April 1847.
} 
cemetery. While the governor was being consulted on the subject, the dragoman buried him in secret in the Christian cemetery with the benediction of the priests of Terra Santa. A diplomatic conflict followed between the governor, Musa Safveti Pasha, who belonged to the faction of the Palace, and the consul of France; each claimed that the deceased was from their religion. ${ }^{112}$ Safveti Pasha wrote to the French consul and accused him of acting in contradiction to the Capitulations. The latter denied this accusation and argued that there was no mention of this type of situation in the Capitulations. ${ }^{113}$ The head priest of Terra Santa then wrote to certify that the man had reverted to Christianity and had wanted to divorce his wife. The governor disregarded this letter and asked for the dragoman to be punished for overstepping his authority. The following day the latter was attacked in the marketplace. ${ }^{114}$ Clearly the politicization of converts could continue even after their deaths.

There was also a problem of inheritance behind this attempt to prove that the deceased had reverted. Since his family had remained Christian, they could not inherit from a Muslim. They could, therefore, have tried to prove his reversion in order to inherit from him and disinherit his wife. The brother of Antoine/Selim Madim, Elias Madim, was imprisoned by Safveti Pasha for entering the house of his brother and taking indemnities on his inheritance. ${ }^{115}$ When Elias Madim was asked in court what his nationality was, he responded that he was a subject of the Porte and a protégé of the Terra Santa convent because this institution paid his share of the taxes. Upon this declaration, he was thrown into prison and kept there for seven days. Ultimately the wife of Antoine/Selim Madim was given her part of the inheritance and the rest was appropriated by the judge. ${ }^{116}$

Even if there was a question of inheritance in the case of Antoine/Selim Madim, the proactive intervention of the consul and the pasha demonstrates that the question went beyond a strictly financial issue. It showed the will to claim a soul, in a sort of spiritual competition that was in fact inherently political: tombs were visual and symbolic representations of communities. The burial of a man in a Muslim or Christian cemetery, located in different areas in the city, represented the superiority of one group over another, and

\footnotetext{
112 A.E. CPC/Turquie/Damas, Safveti Pacha-Bourville, 18 February 1847.

113 A.E. Serie D/166Po/ D2o/3, Tippel-Safveti, 23 February 1847.

114 A.E. CPC/Turquie/Damas, Bourville-Safveti Pacha, 27 February 1847.

115 A.E. Serie D/166Po/D2o/3, Tippel-Baron de Bourquency, 3 February 1847.

116 A.E. Serie D/166Po/D2o/3 Annex to Tippel-Baron de Bourquency, 3 February 1847, "Questions posées au nommé Elias Nadim, frère du défunt Antoine Nadim par Mr Baudin chancelier du consulat et ses réponses."
} 
a political victory during a period in which conversion was a major subject of discussion and a basis for foreign involvement. In this politico-social context, conversion thus became a betrayal of one group and an allegiance to another authority.

Cemeteries were an important way to mark the presence of a community in a city, in addition to being a place of reunion and memory. It is significant that in 1854 the British consul petitioned the governor to demand the construction of a Protestant cemetery in the city for British and American subjects in order to anchor the community in the religious landscape of Damascus. ${ }^{117}$

\section{Conversions between Christian Sects}

Similar cases of contested conversions also took place between Christian communities; these were even more complicated for the Ottoman Empire to handle. ${ }^{118}$ These conversions were, like conversions between Islam and Christianity, also linked to issues of loyalty and foreign influence. Uniates were seen as betraying the Ottoman Empire because of their relation to France and the reign of Muhammad 'Alī. Converts to Protestantism were seen as influenced by the British, while Orthodox were accused of connivance with Russia and the Greek revolts. ${ }^{119}$ Conversions increased the prestige of the respective powers because the international battle for influence also took place on the grounds of faith. In intra-Christian polemics, the different communities accused each other of a lack of loyalty towards the empire, because of their alliance with foreign countries. ${ }^{120}$ Loyalty and religious identity were thus strongly associated.

Conversion was also linked to a fiscal concerns. Indeed, converting to other Christian sects and seeking foreign protection could be a way to escape extreme taxation. ${ }^{121}$ When a hundred Greek Orthodox from the village of H̦āṣbiyya, an area populated by Christians and Druzes, converted to Protestantism in 1844, the Greek Orthodox bishop wrote a letter to the Patriarch of Damascus accusing the converts of having become English. ${ }^{122}$ They were then attacked by members of the Greek Orthodox church, Maronites, and Druzes, who threat-

\footnotetext{
117 F.0. 78/1028, Wood-Earl of Clarendon, 1 February 1854.

118 Deringil, Conversion and Apostasy, 42.

119 Aḥwāl al-nașāra, 20, 21; Masters, Christians and Jews, 130-169.

120 Masters, Christians and Jews, 107.

121 A.E. CPC/ Turquie/Damas, Lewizey-Guizot, 6 March 1844, 8 December 1843, and 30 November 1843 .

122 F.0. 195/226, Annex to Wood-Canning, 4 March 1844, "Translation of a memorial addressed by 100 Orthodox Greeks from Hasbeya to Mr. Consul Wood.”
} 
ened them with death if they did not return to their former faith. ${ }^{123}$ Their conversion not only called into question their relation to the Ottoman state but also their right to reside among their former coreligionists. They thus asked for the protection of the British consul in Damascus, Mr. Richard Wood. He first refused to offer protection, claiming that England did not wish to use religion in order to increase its influence. He even complained about the actions of missionaries, who behaved in a manner that was detrimental to the interests of England. ${ }^{124}$ Apparently, British and American missionaries used to promise to pay the taxes of individuals who converted to Protestantism. ${ }^{125}$ The question of financial responsibilities appears to be at the heart of many issues of conversion. Taxation was closely linked to communal belonging.

Mr. Wood seemed very reticent at first to get involved in this case, and wrote to the pasha refuting the accusations that his agents were the cause of this affair. He did not hesitate to state that this conversion was the consequence of the despair of the converts in the face of excessive taxation. He then reassured the pasha that whatever their religion, the inhabitants of Hâașbiyya were not under British protection. ${ }^{126}$

However, as the case evolved and the Protestants were persecuted, they wrote insistent letters to the British consul, asking for his intervention. ${ }^{27}$ The governor of Damascus, upon learning about this mass conversion, held an exceptional council in order to determine the best possible response to this affair. Some members of the council argued that if the Christians converted in order to escape their condition as subjects of the sultan by using foreign powers, then it was a legally reprehensible act of treason. ${ }^{128}$ Eventually, the Protestants were expelled from their houses in Hasabiyya and while the British consul demanded the punishment of those involved, the Russian general consul in Beirut threatened to intervene if any action was undertaken to humiliate the Greek Orthodox of Hasabiyya. ${ }^{129}$ In the end the pasha of Damascus

\footnotetext{
123 F.o. 195/226, "Deposition of Nicola Haslab, one of the professing Christians Protestants of Hasbeya to the British cancelleria," 27 June 1844.

124 A.E. CPC/ Turquie/Damas, Lewizey-Guizot, 24 March 1844.

125 Ibid.

126 F.o. 195/226, Wood-Canning, "Translation from a Letter from Wood to His excellency Ali Pasha," 29 May 1844.

127 F.o. 195/226, Annex to Wood-Canning, 4 March 1844, "Translation of a memorial"; F.o. 195/226, "Deposition of Nicola Haslab," 27 June 1844.

128 A.E. CPC/ Turquie/Damas, Lewizey-Guizot, 24 March 1844.

129 F.O. 195/226, Wood-Canning, 8 October 1844.
} 
ceded to the pressure of the British consul who accused him of indifference and of not respecting the firman stating that Christians will not be persecuted in the empire. ${ }^{130}$ However, Halil Pasha — the Kapudan Pasha ${ }^{131}$ — and the Russian general consul in Beirut then reminded him that he should support the patriarch who alone was responsible for his community even if some of them converted. ${ }^{132}$ Indeed, the Protestant church was not recognized in the Ottoman Empire until $1847 \cdot{ }^{133}$ Instead of punishing those who pressured the Protestants to return to their original faith, they told the pasha of Damascus that he should encourage them and facilitate their enterprise. ${ }^{134}$

These conflicts over conversion show the politicization of Christian communal identity, which became an additional space of confrontation between the Ottoman Empire and foreign powers. The different communities reacted strongly against those intra-Christian conversions. They saw them as a double treason that damaged the prestige of the church and increased the fiscal burden of the rest of the members of the community who still had to pay taxes for the converted person. ${ }^{35}$

\section{Ambiguities of Subjecthood}

Based on the study of these cases of conversion, it can be observed that two different notions of subjecthood coexisted in this period, a perennial one based on the community as the basis of state-society relations and tied to the land, and another based on the individual, one that took into account his mobility, both physical and religious.

The conflict between these two notions of subjecthood took root in the reform decrees themselves. The reform decrees showed a desire to unite the population and gain the loyalty of the Ottoman subjects. This unity took two different directions. It was underlined both by a will to reinforce the unity of

130 Ibid.

131 The Kapudan Pasha is the grand admiral of the navy of the Ottoman Empire.

132 F.o. 195/226, Annex to Wood-Canning, 8 October 1844, "Letter of his Excellency Halil Pasha to his Excellency Aly Pasha"; F.O. 195/226, Basilios-Aly Pasha, 21 September 1844.

133 F.o. 195/291, Wood-Lord Cowley, 8 January 1848.

134 F.o. 195/226, Annex to Wood-Canning, 8 October 1844, "Letter of his Excellency Halil Pasha to his Excellency Aly Pasha"; F.O. 195/226, Basilios-Aly Pasha, 21 September 1844.

135 Smyrnelis, Une Societé hors de Soi, 71. Taxes were not reassessed often, and thus every year the village had to pay the same amount of taxes, regardless of changes in the number of inhabitants. The taxes on villages instituted by the Egyptians in Damascus had still not been reassessed in 1858, F.o. 198/13, "Report on the Finances of Damascus," 18581860. 
the religious group, which can be called a policy of the millet, and the ideology of an all-inclusive Ottomanism. The two policies contradicted each other. ${ }^{136}$ While Ottomanism was based on the direct relationship of the individual to the state, the policy of the millet reified the religious community as the basis of subjecthood. While individuals were legally allowed to change their religion, the decree of 1856 institutionalized the religious communities in terms of their hierarchy and organization. ${ }^{137}$ The legalization of conversion challenged the authority of the patriarch and the local Christian clergy. Rebellion against the leadership of the church was facilitated by the rise of the Uniate churches. Individuals or groups could threaten to join the Uniate church or vice versa in order to achieve their goals. ${ }^{138}$

Nevertheless, in order to regulate the administration of religious groups, the decree of 1856 strengthened the patriarchs' and laity's authority over their community and harmonized their internal hierarchy. It attributed salaries to the clergy $^{139}$ and created boards composed of both clerical and lay elements in which government officials would have a say. ${ }^{140}$ While giving religious leaders a stronger voice in cases of conversion, this policy also reduced their autonomy. ${ }^{141}$

The bureaucrats found themselves struggling in their attempt to create a social unity on ideological bases and both strategies of fostering unity were simultaneously employed. Those differing objectives may help explain in part the confusion that existed concerning the objectives of the reforms and the practical policies adopted during this period. The lack of clarity of the reforms thus led to a complex situation in which civil servants had difficulties in deciding how to act, who to punish, and whose authority to enforce. These confu-

136 Deringil, Conversion and Apostasy, 31, 38.

137 Benjamin Braude and Bernard Lewis, Christians and Jews in the Ottoman Empire: The Functioning of a Plural Society (New York: Holmes \& Meier Publishers, 1982), 15; Bernard Heyberger, Les Chrétiens Du Proche-Orient: Au Temps de la Réforme Catholique (Syrie, Liban, Palestine, XVIIe-XVIIIe siècles) (Rome: École française de Rome, 1994), 63-107.

138 For example, when the Melkite patriarch decided to replace the existing traditional calendar of Christians in the Middle East with the Gregorian calendar promoted by the Pope, part of the church categorically refused this reform for political or religious reasons. The Uniates in Damascus who refused to adopt the Gregorian calendar mandated by Rome threatened to join the Greek Orthodox church, A.E.CPC, Turquie/Damas, LamartineComte Walewski, 2 October 1857.

139 Hurewitz, Middle East, 1:316-318.

140 Masters, Christians and Jews, 139.

141 See the decree of 1856 in Hurewitz, Middle East, 1:316-318; Smyrnelis, Une Société hors de Soi, 42 . 
sions and ambiguities also gave various actors more leeway to shape the manner in which the reforms were understood, applied, modified or resisted.

In conclusion, the Tanzimat period, characterized by imperial restructuring, foreign intervention, and internal rebellions, turned public space into both an instrument of social transformation and a stake in political struggles. From the Egyptian occupation onwards, the political, social, and economic role of Christians in Damascus was shaped by the structure of international relations, by the reform decrees, and by interactions on the local level between different power representatives. Ottoman societies were composed of a variety of actors who participated in the practice of political power and directed the ways in which the vaguely formulated and ambiguous reforms were applied locally. The consuls and the governors, representing two power institutions, were instrumental in determining the interpretation and enactment of the reforms. Their relationship was punctuated by struggles for sovereignty, especially concerning the issue of protection. The consuls and the governors functioned as two parallel authorities that competed for recognition and legitimacy through their involvement in local conflicts. In this context, specific places in the city became the locus of inter-confessional tensions, as the spatial dynamics of the events of 1860 indicate. Public displays such as sartorial customs and the built environment were also used by all parties to bolster their positions; daily practices thus contributed to the political polarization of religious groups. The case study of conversion demonstrates that in the context of the Tanzimat, faith became an issue of loyalty and sovereignty. Conversion developed into a political shift of allegiance. Spiritual competition was a continuation of international politics at the local level. The legal, political, and social difficulties arising from the cases of conversion point to the transitional nature of the Tanzimat period, during which the relations between the empire and its subjects were radically transformed. Because of the tensions between notions of individual and communal subjecthood in the reforms, relations between non-Muslims and the Ottoman state were unclear. This lack of clarity allowed for the involvement of a variety of actors speaking in the name of Ottoman Christians. While this involvement provided economic and political opportunities for some individuals, it led to a general deterioration of inter-confessional relations, and this had dire consequences for the Christians of Damascus. 


\section{Bibliography}

\section{Primary Sources}

Archives

British Foreign Office (F.O.), Damascus: 1837-186o, National Archives, London.

Affaires Etrangères (A.E.) Correspondance Politique des Consuls (CPC)/Turquie, Damas: 1826-1896, Archives Consulaires du Ministère des Affaires Etrangères, La Courneuve, France.

Affaires Etrangères (A.E.) Mémoires et Documents de Turquie, Archives Consulaire du Ministère des Affaires Etrangères, La Courneuve, France.

\section{Chronicles}

Aḥwāl al-nașāra ba'd al-harb al-qaram. Ms, Catalogue Cheikho. Beirut: Saint Joseph University.

'Awra, Ibrāhīm.Tārīkh wilāya Sulāyman Basha al-ādilyashtamilu 'ala tārīkh Filasținn waLubnān. Edited by al-Kuri Qustanțīn al-Basha. Sayda: Matbacāt Dār al-Mukkhāllis, 1936.

Mishāqah, Mikhā̄īl. Kitāb mashhad al-'ayān bi-hawādith Sūriya wa-Lubnān. Edited by Milham Khālis 'Abduh and Andrawus Hanna Shakhashiri. Cairo, 1908.

Mudhakkirat tārīkhiyya 'an hamlat Ibrāhìm bāsha 'ala Sūriya. Edited by Aḥmad Ghassān Sabanu. Damascus: Dār Qutayba, 1980.

al-Ustwānī, Muḥammad Sa`̄ì̄. Mashāhid wa-ahdāth Dimashq fì muntaṣaf al-qarn altasi' 'ashar, 1256-1277 H, 1840-1861. Edited by Assad al-Ustwānī. Damascus, 1994.

\section{Secondary Sources}

Abu-Manneh, Butrus. "The Later Tanzimat and the Ottoman Legacy in the Near Eastern Successor States." In Camille Mansour, Leila Fawaz (eds.), Transformed Landscapes: Essays on Palestine and the Middle East in Honor of Walid Khalidi, 61-82. Cairo: American University of Cairo Press, 2009.

Studies on Islam and the Ottoman Empire in the 19th Century (1826-1876). Analecta Isisiana. Istanbul: Isis Press, 2001.

. "The Sultan and the Bureaucracy: The Anti-Tanzimat Concepts of Grand Vizier Mahmud Nedim Pasa." International Journal of Middle East Studies 22, no. 3 (1990): 257-274.

Banī Hānī, Khālid. Tārīkh Dimashq wa-'ulamā̉iha khilāl al-ḥukm al-Mișrī, 1831-1840. Damascus: Dār Ṣafhāt, 2007.

Beinin, Joel. Workers and Peasants in the Modern Middle East. The Contemporary Middle East. Cambridge/New York: Cambridge University Press, 2001.

Braude, Benjamin and Bernard Lewis. Christians and Jews in the Ottoman Empire: The Functioning of a Plural Society. New York: Holmes \& Meier Publishers, 1982. 
Darling, Linda T. A History of Social Justice and Political Power in the Middle East: The Circle ofJustice From Mesopotamia to Globalization. New York: Routledge, 2013.

Deringil, Selim. Conversion and Apostasy in the Late Ottoman Empire. Cambridge: Cambridge University Press, 2012.

- "There is no Compulsion in Religion: On Conversion and Apostasy in the Late Ottoman Empire: 1839-1856." Comparative Study of Society and History 42, no. 3 (2000): 547-575.

Donzel-Verdeil, Chantal. "Les Jésuites de Syrie (1830-1864): Une Mission auprès des Chrétiens d' Orient au début des Réformes Ottomanes." PhD dissertation, University Paris IV Sorbonne, 2003.

Edwards, Richard. La Syrie 1840-1862, histoire, politique, administration, population, religion et mours, évènements de 1860 d'après des actes officiels et des documents authentiques. Paris: Amyot, 1862.

Farah, Ceasar E. The Politics of Interventionism in Ottoman Lebanon, 1830-1861. London: I.B. Tauris, 2000.

Figes, Orlando. The Crimean War: A History. New York: Metropolitan Books, 2010.

Findley, Carter V. Bureaucratic Reform in the Ottoman Empire: The Sublime Porte, 17891922. Princeton, NJ: Princeton University Press, 1980.

Frankel, Jonathan. The Damascus Affair. Cambridge: Cambridge University Press, 1997. Ginio, Eyal. "Coping with the State's Agents 'from below': Petitions, Legal Appeal, and the Sultan's Justice in Ottoman Legal Practice." In Eleny Gara, Mustafa E. Kabadayı, Christoph K. Neumann (eds.), Popular Protest and Political Participation in the Ottoman Empire: Studies in Honor of Suraiya Faroqhi, 41-56. Istanbul: Istanbul Bilgi University Press, 2011.

Hajjar, Joseph. Les Chrétiens Uniates du Proche-Orient. Paris: Edition du Seuil, 1962.

Heyberger, Bernard. Les Chrétiens Du Proche-Orient: Au Temps de la Réforme Catholique (Syrie, Liban, Palestine, xviie-xviiie siècles) Bibliothèque des Écoles Françaises d'Athènes et de Rome. Rome: École française de Rome, 1994.

Hofman, Yitzhak. “The Administration under Egyptian Rule." In Moshe Macoz (ed.), Studies on Palestine during the Ottoman period, 311-334. Jerusalem: Magnes Press, 1975.

Hurewitz, Jacob C. (ed.). The Middle East and North Africa in World politics. Vol. 1. New Haven, Ст: Yale University Press, 1975-1979.

van Leeuwen, Richard. Waqfs and Urban Structures: The Case of Ottoman Damascus. Studies in Islamic Law and Society. Leiden: Brill, 1999.

Massot, Anais. "Modernization, Communal Space and Inter-confessional Conflicts in 19th century Damascus." Syrian Studies Association Bulletin 17, no. 2 (2012): 12-15.

Masters, Bruce Alan. Christians and Jews in the Ottoman Arab World: The Roots of Sectarianism. Cambridge Studies in Islamic Civilization. New York: Cambridge University Press, 2001. 
Mishaqah, Mikha'il. Murder, Mayhem, Pillage, and Plunder. Translated by Wheeler M. Thackston. New York: State University of New York Press, 1988.

Philipp, Thomas. "Class, Community, and Arab Historiography in the Early Nineteenth Century-the Dawn of a New Era." International Journal of Middle East Studies 16, no. 2 (1984):161-175.

Quataert, Donald. "Clothing Laws, State, and Society in the Ottoman Empire, 17201829." International Journal of Middle Eastern Studies 29, no. 3 (1997): 403-425.

Rafeq, Abdul-Karim. "The Impact of Europe on a Traditional Economy: The Case of Damascus, 1840-1870." In Jean Louis Bacqué-Grammont and Pierre Dumont (eds.), Économie et Sociétés dans l'Empire Ottoman, fin du XVIIIe-début du xxe siècle: Actes du Colloque de Strasbourg, ter-5Juillet 1980, 419-432. Paris: Éditions du Centre national de la recherche scientifique, 1983 .

Schatkowski Schilcher, Linda. Families in Politics: Damascene Factions and Estates of the 18th and 19th Centuries. Berliner Islamstudien. Wiesbaden: F. Steiner, 1985.

Smyrnelis, Marie Carmen. Une Société hors de Soi: Identités et Relations Sociales à Smyrne aux XVIIIe et XIXe siècles. Collecte Turcica 10. Leuven: Peeters Publishers, 2005 .

Tarazi Fawaz, Leila. An Occasion for War: Civil Conflict in Lebanon and Damascus. Berkeley: University of California Press, 1994.

Tomeh, George Ramez. "Landownership and Political Power in Damascus 1858-1958." PhD dissertation, American University of Beirut, 2007.

Weber, Stefan. Damascus: Ottoman Modernity and Urban Transformation (1808-1918). Proceedings of the Danish Institute in Damascus. Vol. 1 and 2. Aarhus Denmark: Aarhus University Press, 2009.

Weismann, Itzchak. "Law and Sufism on the Eve of Reform: The Views of Ibn 'Abidin." In Itzchak Weismann and Fruma Zachs (eds.), Ottoman Reform and Muslim Regeneration, 69-80. New York: I.B. Tauris, 2005.

Zandi-Sayek, Sibel. "Orchestrating Difference, Performing Identity: Public Rituals in Nineteenth-Century Izmir." In Nezar AlSayyad (ed.), Hybrid Urbanism: On the Identity Discourse and the Built Environment, 42-66. Westport, Ст: Praeger, 2001. 